\title{
Prevalensi Atrioventrikular Blok di RSUP Prof. Dr. R. D. Kandou Manado Periode 2013 - 2014
}

\author{
1 Jery Wambrauw \\ ${ }^{2}$ Edmond L. Jim \\ ${ }^{2}$ Victor F. F. Joseph \\ ${ }^{1}$ Kandidat Skripsi Fakultas Kedokteran Universitas Sam Ratulangi \\ ${ }^{2}$ Bagian Kardiologi FK Unsrat Manado/RSUP Prof. DR. R. D. Kandou Manado. \\ Email: jerywambrauw12022@gmail.com
}

\begin{abstract}
AV Block conduction is an abnormality in which the impulse from the atrium has a delayed conduction or no conduction at all to the ventricle. This abnormality is classified as AV Block first degree, second degree, and third degree, depending on the severity of the abnormality. This was a descriptive retrospective study using second data as the reference. This study was aimed to obtain the prevalence of atrioventricular block at Cardiology Clinic Prof. Dr. R. D. Kandou Hospital Manado during 2013 - 2014. The results showed that of 40 patients, the highest percentage of cases had third degree AV block (21 patients; 53\%), age group of 70-79 years (33\%). Based on gender, there was the same number of cases of males and females, but the classification based on the degree of AV block showed that there were more male patients diagnosed as AV block first degree while there were more female patients diagnosed as third degree AV block. Hypertension was commonly found in the patients diagnosed as AV block as many as 18 patients (27\%). Based on the chief complaint, most had difficulty of breathing (28\%). However, each degree of the AV block had varied chief complaints and different kind of therapy. Based on the management, $77 \%$ of the patients had medical therapy with different kinds of medication.
\end{abstract}

Keywords: AV block

\begin{abstract}
Abstrak: Blok konduksi AV merupakan kelainan yang mana impuls dari atrium dikonduksikan terlambat atau bahkan tidak dikonduksikan sama sekali ke ventrikel. Kelainan ini diklasifikasikan sebagai blok AV derajat satu, dua, dan tiga, tergantung pada keparahan abnormalitasnya. Penelitian dan bertujuan untuk mengetahui prevalensi blokade atrioventrikular di poli jantung RSUP Prof. Dr. R. D. Kandou Manado selama selang waktu 2013 - 2014. Jenis penelitian ialah deskriptif retrospektif menggunakan data sekunder sebagai acuan. Hasil penelitian mendapatkan dari 40 pasien, terbanyak ditemukan ialah AV blok derajat III (21 pasien; 53\%); kelompok usia 70-79 tahun (33\%). Berdasarkan jenis kelamin didapatkan jumlah yang sama antara pasien laki-laki dan perempuan, namun dalam pembagian berdasarkan derajat AV blok didapatkan pasien laki-laki lebih banyak dengan diagnosis AV blok derajat I sedangkan perempuan lebih banyak pada AV blok derajat III. Penyakit penyerta terbanyak ditemukan ialah hipertensi (18 pasien; 27\%). Berdasarkan keluhan penyerta pada pasien AV blok terbanyak ditemukan ialah sesak nafas (28\%) namun untuk masing-masing derajat AV blok keluhan yang paling sering dialami berbeda-beda, dan berdasarkan penatalaksanaan yang diberikan $77 \%$ pasien di terapi dengan obat-obatan.
\end{abstract}

Kata kunci: AV blok

Blok konduksi AV merupakan kelainan yang mana impuls atriumdi konduksikan terlambat atau bahkan tidak di konduksikan sama sekali ke ventrikel. Kelainan ini 
diklasifikasikan sebagai blok AV derajat satu, dua, dan tiga, tergantung pada keparahan abnormalitasnya. ${ }^{1}$

Blok AV derajat I dikarakteristikan dengan pemanjangan abnormal interval PR di atas $200 \mathrm{~ms}(>0,2 \mathrm{~s})$. Setiap gelombang $\mathrm{P}$ diikuti dengan gelombang QRS, namun dengan pemanjangan interval PR yang konstan. Pemanjangan interval PR paling sering terjadi akibat keterlambatan konduksi di dalam AV node. Blok AV derajat I biasanya tidak menimbulkan gejala. $^{2}$ Ablok AV derajat II ditandai dengan adanya satu atau lebih stimulus yang tidak di kenduksikan ke ventrikel. ${ }^{3}$ Blok AV derajat II di subklasifikasikan menjadi tipe I dan tipe II. ${ }^{4}$ Blok AV derajat II tipe 1 dikarakteristikan dengan pemanjangan interval PR secara progresif yang muncul sebelum gelombang $\mathrm{P}$ yang tidak terkonduksikan (non conducted $P$ wave) atau disebut perilaku Weckenbach. Pada Mobitz tipe II, interval PR tetap sama tetapi didapatkan denyut ventrikel yang berkurang (dropped beat). Kekurangan denyut ventrikel dapat teratur atau tidak seperti 2:1, 4:1, 4:3 dan sebagainya. Blok AV derajat III disebut juga blok jantung komplit. Pada blok AV derajat III impuls dari atrium tidak bisa sampai di ventrikel. ${ }^{1}$

Dua dari 100 pasien dengan serangan jantung, mengalami kerusakan jalur konduksi listrik yang menghubungkan atrium dan ventrikel (nodus AV dan His bundle) dan mengakibatkan penurunan heart rate. Beberapa faktor lain juga berperan seperti penyakit degeneratif idiopatik, infeksi (Chagas disease, Lyme disease, Viral Miokarditis), penyakit vaskular kolagen, infiltrative disease, dan penyakit neuromuskular. ${ }^{5}$

Pasien blok AV bisa tanpa gejala atau asimptomatis atau bisa juga mengalami gejala serius yang berhubungan dengan bradikardia, aritmia ventrikel, atau bahkan keduanya. ${ }^{4}$ Pasien dengan blok AV derajat I biasanya tanpa gejala. ${ }^{2}$ Pada penelitian sebelumnya menunjukkan blok AV derajat I merupakan temuan jinak tanpa makna prognosis pada pasien yang sehat dan berisiko rendah penyakit kardiovaskuler. ${ }^{6}$
Blok AV derajat II jarang menimbulkan gejala, namun Mobitz tipe II bisa berprogresi menjadi blok AV derajat III. ${ }^{1}$

Secara klinis, pasien dengan blok AV derajat III dapat mengalami fatigue atau sinkop, tergantung pada kecepatan dari ventricular escape. Pada usia lanjut blok AV derajat III biasanya menimbulkan gangguan hemodinamika dan menimbulkan keluhan lelah, sinkop, sesak dan angina. ${ }^{2}$

EKG biasanya menyedikan informasi untuk jenis dan lokalisasi blok (jika rekaman cukup panjang). ${ }^{2}$ Blok AV derajat I adalah delay impuls yang melewati nodus AV lebih panjang. Kriteria diagnosis ialah perpanjangan interval $\mathrm{PR}>0,2 \mathrm{sec}$; irama regular; semua denyut dikonduksikan dari atrium ke ventrikel. Kriteria pada Mobitz tipe I (Wenckebach) ialah interval gelombang PR meningkat secara bertahap sampai satu gelombang $\mathrm{P}$ gagal dikonduksikan ke ventrikel. Pada Mobitz II interval PR teratur, terjadi blok intermiten konduksi gelombang $\mathrm{P}$ ke ventrikel. Blok AV derajat III ditandai dengan gangguan konduksi $\mathrm{AV}$, gelombang $\mathrm{P}$ tidak saling berhubungan dengan kompleks QRS, denyut ventrikel lebih lambat. ${ }^{7}$

Pasien blok AV bisa tanpa gejala atau asimtomatis, atau bisa juga mengalami gejala serius yang berhubungan dengan bradikardia, aritmia ventrikel, atau bahkan keduanya. ${ }^{4}$ Pasien dengan blok AV derajat I biasanya tanpa gejala, ${ }^{2}$ dan merupakan temuan jinak tanpa makna prognosis pada pasien yang sehat dan berisiko rendah penyakit kardiovaskuler. ${ }^{6}$

Tujuan dari evaluasi dan manajemen blok AV ialah untuk mencegah kematian dan morbiditas dengan: (1) Dukung denyut jantung pada pasien dengan bradikardia; (2) Monitoring dan siaga untuk dukungan denyut jantung pada pasien berisiko tinggi untuk asistol atau bradikardi berat; (3) Mengidentifikasi dan menangani penyebab reversibel blok AV; (4) Mengidentifiikasi pasien dengan risiko tinggi kematian mendadak (ssudden death), sinkop, atau gejala blok AV yang kambuh; dan (5) memilih dan mengimplan alat pacu jantung yang tepat segera setelah mendapat izin. ${ }^{8}$ 
Blok AV derajat I bersifat jinak dan kondisi asimtomatis yang tidak membutuhkan pengobatan, tetapi dapat menunjukan penyakit pada nodus AV yang rentan terhadap blok AV derajat yang lebih tinggih. $^{9}$ Alat pacu jantung sementara dan permanen adalah therapy of choice dri sebagian besar kasus blok AV total dengan gejala. Indikasi tergantung oleh tipe dan lokasi, gejala yang ada, prognosis dan penyakit yang menyertai. ${ }^{2}$

Prognosis pasien dengan gangguan konduksi AV tergantung pada lokasi blok, tetapi juga terutama pada penyakit jantung yang menyertai atau yang mendasari. ${ }^{2}$

\section{METODE PENELITIAN}

Jenis penelitian ini ialah deskriptif retrospektif dengan cara mengumpulkan data rekam medik pasien AV blok di Poli jantung RSUP Prof. Dr. R. D. Kandou periode 2013-2014. Sampel penelitian ini ialah semua pasien AV blok yang dirawat di RSUP Prof dr. R. D. Kandou Manado periode 2013-2014. Variabel yang diteliti ialah usia, jenis kelamin, keluhan yang menyertai, penyakit yang menyertai, dan jenis penatalaksanaan yang diberikan.

\section{HASIL PENELITIAN}

Pada penelitian ini didapatkan jumlah pasien AV Blok periode 2013-2014 sebanyak 62 orang dan yang termasuk dalam kriteria inklusi pada penelitian ini sebanyak 40 orang.

Tabel 1 menunjukkan jumlah dan persentase pada masing-masing derajat AV blok. Pada penelitian ini tidak ditemukan pasien AV blok derajat II tipe II. Paling banyak pasien pada AV blok derajat III dengan jumlah 21orang (52,5\%). Dari 40 pasien AV blok yang diteliti didapatkan jumlah seimbang antara laki-laki dan perempuan yaitu 20 orang laki-laki dan 20 rang perempuan.

Tabel 2 menunjukkan bahwa pasien AV blok dengan jenis kelamin laki-laki lebih banyak dengan diagnosis dengan AV blok derajat I sebanyak 11 orang atau 55\% dari semua pasien laki-laki. Pada perempuan lebih banyak dengan diagnosis
AV blok derajat III dengan jumlah 14 orang atau $70 \%$ dari semua pasien perempuan.

Tabel 1. Jumlah dan persentase pasien AV pada tiap derajat AV blok

\begin{tabular}{lcc}
\hline Derajat AV blok & N & \% \\
\hline Derajat I & 16 & $40 \%$ \\
Derajat II tipe I & 3 & $7,5 \%$ \\
Derajat II tipe II & - & - \\
Derajat III & 21 & $52,5 \%$ \\
\hline
\end{tabular}

Tabel 2. Jumlah pasien AV blok berdasarkan jenis kelamin pada masing-masing derajat AV blok

\begin{tabular}{lcc}
\hline Derajat AV blok & Laki-laki & Perempuan \\
\cline { 2 - 3 } & \multicolumn{2}{c}{$(\mathrm{n})$} \\
\hline Derajat I & 11 & 5 \\
Derajat II tipe I & 2 & 1 \\
Derajat II tipe II & - & - \\
Derajat III & 7 & 14 \\
Jumlah & 20 & 20 \\
\hline
\end{tabular}

Berdasarkan kelompok usia pada masing-masing derajat AV blok dapat dilihat pasien AV blok terbanyak pada usia $>70$ tahun dengan jumlah 16 orang dan paling sedikit pada kelompok usia 50-59 tahun dengan jumlah 5 orang (Tabel 3).

Tabel 4 memperlihatkan bahwa hipertensi merupakan penyakit penyerta yang paling banyak ditemukan pada pasien dengan AV blok yang didapati pada 18 pasien (27\%).

Tabel 3. Jumlah pasien AV blok berdasarkan kelompok usia pada masing-masing deerajat AV blok

\begin{tabular}{lcccc}
\hline Usia & $\begin{array}{c}\text { AVB } \\
\text { derajat } \\
\text { I }\end{array}$ & $\begin{array}{c}\text { AVB } \\
\text { derajat } \\
\text { II tipe I }\end{array}$ & $\begin{array}{c}\text { AVB } \\
\text { derajat } \\
\text { III }\end{array}$ & Jumlah \\
\cline { 2 - 5 } & \multicolumn{4}{c}{$\mathrm{N}$} \\
\hline$<49$ & 4 & 1 & 3 & 8 \\
$50-59$ & 2 & 1 & 2 & 5 \\
$60-69$ & 5 & & 6 & 11 \\
$>70$ & 5 & 1 & 10 & 16 \\
Jumlah & 16 & 3 & 21 & 40 \\
\hline
\end{tabular}


Tabel 4. Distribusi pasien AV blok berdasarkan penyakit yang menyertai.

\begin{tabular}{lcc}
\hline Penyakit yang menyertai & \multicolumn{2}{c}{ Jumlah } \\
\cline { 2 - 3 } & $\mathrm{N}$ & $\%$ \\
\hline Hipertensi & 18 & $27 \%$ \\
Congestive Heart Failure & 10 & $15 \%$ \\
Chronic Kidney Disease & 9 & $14 \%$ \\
Premature Ventricular & & \\
Contraction & 4 & $6 \%$ \\
Sindrom koroner akut & & \\
STEMI & 4 & $6 \%$ \\
Old Myocard Infarct & 4 & $6 \%$ \\
Coronarry Artery Disease & 4 & $6 \%$ \\
Left Bundle Branch Block & 4 & $6 \%$ \\
Miocard Infarct & 3 & $5 \%$ \\
Dyslipidemia & 2 & $3 \%$ \\
Diabetes Mellitus & 2 & $3 \%$ \\
Penyakit Jantung Iskemik & 1 & $1,5 \%$ \\
Infark Miokard Akut & 1 & $1,5 \%$ \\
\hline
\end{tabular}

Pada penelitian ini didapatkan data tentang keluhan yang menyertai pasien AV blok. Terdapar $22 \%$ pasien dengan keluhan sesak nafas, $18 \%$ pasien dengan keluhan mual-mual, $16 \%$ pasien dengan nyeri dada, $15 \%$ pasien dengan keluhan muntahmuntah, $13 \%$ pasien dengan keluhan pingsan, $9 \%$ pasien dengan keluhan pusing, dan $7 \%$ pasien dengan keluhan berdebardebar. Gambar 1 menunjukkan keluhan yang menyertai pasien AV blok derajat I, dan dapat dilihat bahwa keluhan yang paling banyak menyertai ialah mual $(31 \%)$, dan yang paling sedikit ialah berdebardebar $(7 \%)$.
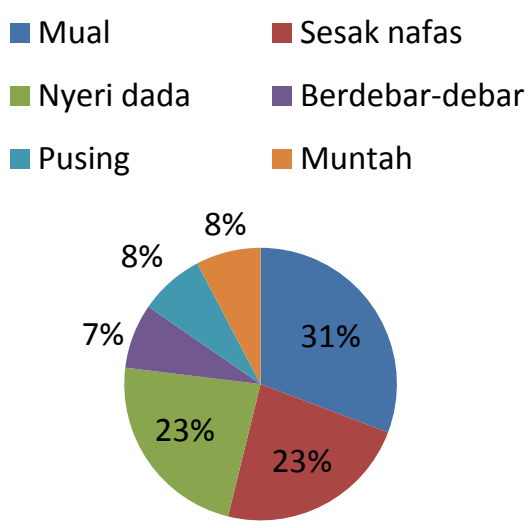

Gambar 1. Distribusi pasien AV blok derajat I berdasarkan keluhan yang menyertai
Pada AV blok derajat II tipe I didapatkan tiga keluhan yang menyertai (Gambar 2). Sesak nafas merupakan keluhan yang paling banyak dengan persentase $34 \%$.

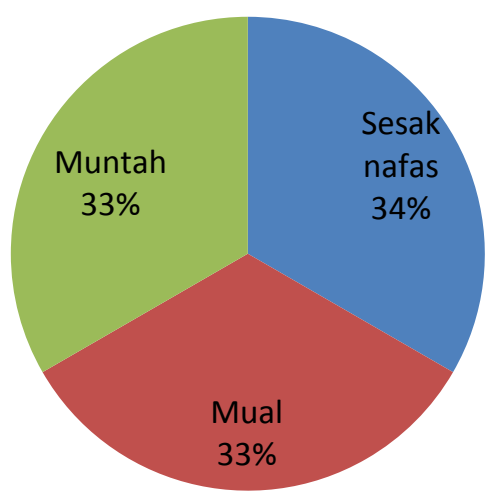

Gambar 2. Distribusi pasien AV blok derajat II tipe I berdasarkan keluhan yang menyertai

Keluhan yang menyertai pada AV blok derajat III paling banyak ditemukan ialah pingsan dan sesak nafas dengan jumlah persentase masing-masing $21 \%$ dan yang paling sedikit ialah berdebar-debar (7\%).

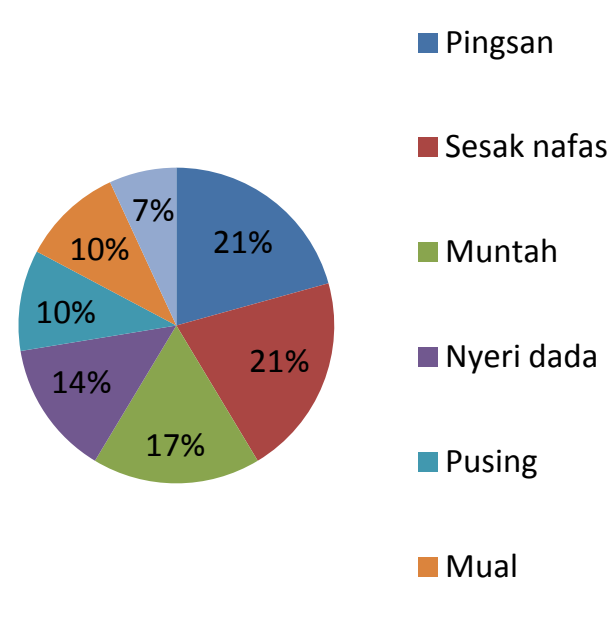

Gambar 3. Distribusi pasien AV blok deerajat III dengan keluhan yang menyertai

Tabel 5 menunjukkan bahwa jenis terapi yang paling banyak diberikan adalah medikamentosa 30 orang $(75 \%)$. Pemasangan pacemaker 6 orang $(15 \%)$ dan yang tidak diberikan terapi ada 3 orang $(7,5 \%)$. 
Tabel 5. Jenis terapi yang diberikan pada pasien AV blok berdasarkan derajat AV blok

\begin{tabular}{lrrcc}
\hline \multirow{2}{*}{ Terapi } & \multicolumn{3}{c}{ Derajat } & \multirow{2}{*}{ Jumlah } \\
\cline { 1 - 4 } & I & II & III & \\
\hline Medikamentosa & 13 & 3 & 15 & 30 \\
Pacemaker & 0 & 0 & 6 & 6 \\
Tidak ada & 3 & 0 & 0 & 4 \\
Jumlah & 16 & 3 & 21 & 40 \\
\hline
\end{tabular}

\section{BAHASAN}

Dari 40 pasien yang diteliti, didapatkan AV blok terbanyak ialah AV blok derajat III $(n=21)$, diikuti dengan AV blok derajat I $(n=16)$, dan AV blok derajat II tipe I $(n=3)$. Tidak ditemukan pasien AV blok derajat II tipe II (Mobitz II). Prevalensi AV blok derajat I meningkat dengan bertambahnya usia. Hal ini sesuai dengan acuan pustaka yang menyatakan bahwa dengan bertambahnya usia, lebih sering ditemukan perkembangan gangguan konduksi AV. Dalam studi epidemiologi dari 1500 pasien lebih tua dari 65 tahun, defek konduksi AV dan konduksi intraventrikular ditemukan pada $30 \%$ pasien. ${ }^{10}$

AV blok derajat I didefinisikan sebagai interval PR yang >200 ms, menunjukkan keterlambatan dalam konduksi AV pada nodus AV. Kondisi ini biasanya tanpa gejala dan berhubungan dengan penuaan normal. Prevalensi tingkat pertama blok AV pada orang muda yang sehat ialah sekitar 3-4\%, yang pada orang tua beberapa kali lipat lebih besar dari pada orang muda. $^{11}$

Pada penelitian ini ditemukan bahwa prevalensi AV blok derajat I $(n=16)$ dan paling banyak ditemukan pada kelompok umur 60-80 tahun $(\mathrm{n}=10)$. Menurut Upshaw, ${ }^{12}$ dalam studi perbandingan dari prevalensi AV blok derajat I pada kelompok etnis Afrika-Amerika dan Kauskasia ditemukan peningkatan prevalensi AV blok derajat I dengan bertambahnya usia. $6,9 \%(n=64$ dari 922) pada pasien Afrika-Amerika, pasien Kaukasia $7,0 \%(\mathrm{~N}=84$ dari 1.201).

Berdasarkan hasil penelitian didapatkan bahwa AV blok derajat I lebih sering ditemukan pada laki-laki $(\mathrm{n}=11)$ dibanding perempuan $(n=5)$. Menurut Upshaw, ${ }^{12}$ tingkat pertama AV blok lebih umum pada laki-laki $(7,6 \%)$, dibandingkan dengan perempuan $(6,5 \%)$ di kedua etnis kelompok namjun tidak terdapat hubungan yang bermakna.

Pada penelitian ini ditemukan 3 pasien dengan AV blok derajat II (Mobitz I) dan untuk penatalaksanaan tidak diberikan alat pacu jantung.

AV blok derajat II Wenckebach (Mobitz I) dianggap jinak. Dilaporkan bahwa di rumah sakit umum distrik di Inggris, 200 pasien yang diberikan alat pacu jantung tidak tidak ditemukan pasien dengan Mobitz I. ${ }^{13}$

Menurut studi Reykjavik prevalensi atrioventrikular blok derajat III umumnya rendah. Atrioventrikular blok derajat III ditemukan pada 11 orang, 7 laki-laki dan 4 perempuan, dengan prevalensi keseluruhan $0,04 \%$. AV blok sementara pada 7 orang (64\%); 6 (55\%) membutuhkan alat pacu jantung. ${ }^{14}$ Hal ini bertolak belakang dengan hasil penelitian ini, yaitu AV blok derajat III yang paling banyak dengan jumlah pasien 21 orang $(53 \%)$ terdiri dari 7 orang laki-laki dan 14 perempuan.

Pada penelitian ini juga didapatkan dari semua pasien AV blok derajat III hanya 6 orang $(28.5 \%)$ yang menyetujui dan dipasang alat pacu jantung. Menurut Volger dan Eckardt, ${ }^{2}$ dengan tidak adanya alat pacu jantung maka pasien dengan AV blok total memiliki prognosis yang sangat buruk dengan tingkat ketahanan hidup 1 tahun hanya 50\%-70\% (dibandingkan dengan jenis kelamin dan populasi kontrol usia yang sama) setelah mengalami sinkop karena AV blok total.

Pada penelitian ini didapatkan juga $8 \%$ pasien tidak diberikan intervensi medikamentosa maupun pemasangan pacemaker; seluruhnya merupakan pasien dengan diagnosis blok AV derajat I. Menurut acuan pustaka, AV blok derajat I biasanya jinak dan tidak membutuhkan perawatan, namun harus diobservasi untuk kemungkinan perkembangan ke derajat yang lebih tinggi. $^{2}$ 


\section{SIMPULAN}

Prevalensi AV blok untuk periode 2013-2014 secara umum lebih tinggi daripada AV blok derajat III. Prevalensi AV blok derajat II tipe I yang paling rendah untuk periode 2013-2014. Tidak ditemukan AV blok derajat II tipe II. Prevalensi AV blok derajat meningkat berdasarkan bertambahnya usia. Prevalensi AV blok berdasarkan jenis kelamin secara umum seimbang namun berbeda-beda untuk masing-masing derajat AV blok. Keluhan yang sering muncul pada pasien AV blok ialah sesak namun dapat berbedabeda untuk tiap derajat.

\section{SARAN}

Diharapkan hasil penelitian ini dapat menambah pengetahuan tentang AV blok dan pada penelitian selanjutnya diharapkan dapat dikembangkan ke skala yang lebih besar dan dengan sampel yang lebih banyak.

\section{DAFTAR PUSTAKA}

1. Aryu W, Sudoyo BS, Alwi I, Simadibrata MK, Setiati S, Syam AF. Buku Ajar Ilmu Penyakit Dalam (6th ed). Jakarta: Interna Publishing, 2014; p. 1352.

2. Volger JBG, Eckardt L. Bradyarrhythmias and conduction blocks. Rev Esp Cardiol. 2012;7(65):656-7.

3. Brignole $M$, Auricchio AGB-E, Bordachar P, Boriani G, Ole-A B, Cleland $\mathbf{J}$, et al. Guidelines for cardiac pacing and cardiac resynchronization therapy. Eur Heart J. 2013(34):2281-329.

4. Epstein AE, Ellenbogen KA, Mark Estes NA, Freedman RA, Gettes LS, Gillinov AM, Gregoratos G, et al. ACC/AHA/HRS Guidelines for device-based therapy. Circulation.
2008; 117:350-408.

5. Khan MG. Encyclopedia of Heart Diseases. California: Elsevier Inc, 2006.

6. Ryan K, Crisel RF-F, Beeya NA, Whooley MA. First-degree atrioventricular block is associated with heart failure and death in persons with stable coronary artery disease: data from the Heart and Soul Study. Eur Heart J. 2011(10):139.

7. Kulkam AP, Patil VP, Gehdoo RP. Objective anaesthesia review a comprehnsive textbook for the examinees. New Delhie: Jaypee Brothers Medical Publishers (P)Ltd, 2013.

8. Bope ET. Conn's Current Therapy. Philadelphia: Saunders. An inprint of Elsevier Inc, 2014.

9. Lilly LS. Pathophysiology of Heart Disease. Baltimore: Lippincott Williams \& Willkins, a Wolters Kluwer Business, 2011.

10.Saksena SAJC. Electrophysiological Disorders of the Heart. Philadelphia: Saunders. An inprint of Elsevier.Inc, 2012.

11.Chow GV, Marine JE, Fleg JL. Epidemiology of arrhythmias and conduction disorders in older sdults. Clin Geriatr Med. 2012;28(4):539-53.

12.Upshaw CB. Comparison of the prevalence of first-degree atrioventricular block in African-American and in Caucasian patients: an electrocardiographic study III. J Natl Med Assoc. 2004;96(6):756-60.

13.Shaw DB, Gowers JI, Kekwick CA, New KHJ, Whistance AWT. Is Mobitz type I atrioventricular block benign in adults? Heart. 2004;90(2):169-74.

14. The prevalence and prognosis of thirddegree atrioventricular conduction block: the Reykjavik study. J. Intern. Med. 1999;246(1):81-6. 